\title{
Protamine dosage effects on complement activation and sonoclot coagulation analysis after cardiac surgery
}

\author{
Christian Schaub 1 , Thomas OD ${ }^{2}$, Åkervall Fridh $\mathrm{L}^{3}$ and Ulf Schött ${ }^{4 *}$ \\ *Correspondence: ulf.schott@skane.se \\ ${ }^{1}$ University hospital Giessen und Marburg and Erasmus Programme, Germany. \\ ${ }^{2}$ Lund University and Skane University Hospital Department of Anaesthesiology and Intensive Care, S-22185, Lund, Sweden. \\ ${ }^{3}$ Örebro University Hospital, Department of Cardiothoracic Anaesthesiology and Intensive Care S-701 85 Örebro, Sweden. \\ ${ }^{4}$ Lund University and Skane University Hospital Department of Anaesthesiology and Intensive Care, S-22185, Lund, Sweden.
}

\begin{abstract}
Background: An optimal dosage and infusion regime for protamine reversal of heparin after cardiopulmonary bypass is important.

Methods: Protamine dosages of either $2 \mathrm{mg} / \mathrm{kg}$ or $4 \mathrm{mg} / \mathrm{kg}$ bodyweight were compared in 40 patients after first time coronary arterial bypass grafting. Protamine was infused with a syringe driver over 20 minutes. Arterial blood sampling was performed prior to and during surgery, before and at $0.3,0.6,1,3,6$ and $25 \mathrm{~h}$ after the protamine infusion. C3a-desArg and C4a-desArg were analysed by radioimmunoassay. Coagulation was assayed with Sonoclot and activated clotting time.

Results: Significantly higher inter-group plasma levels of C3a-desArg were seen with the greater protamine dose from 0.3 $0.6 \mathrm{~h}$, but none for $\mathrm{C} 4 \mathrm{a}$-desArg. Sonoclot parameters and leucocyte count differed significantly between the groups up to $6 \mathrm{~h}$, indicating hypercoagulabilty with the higher protamine dose. Significantly longer ACT in the low protamine dosage group indicited unblocked heparin with nonsignificant increased drainage bleeding and transfusions. There were no signs of allergic or anaphylactic reactions in any of the groups.

Conclusion: Keeping the protamine dose low, minimizes complement activation with less viscoelastic signs of hypercoagulability. However there is an increased risk for drainage bleeding and unnecessary transfusion if heparin is not fully reversed with protamine post cardiopulmonary bypass. The present study was underpowered to detect significant differences in bleeding.
\end{abstract}

Keywords: Protamine, complement activation, C3a, sonoclot, cardiopulmonary bypass surgery

\section{Introduction}

Several adverse reactions may occur after intravenous protamine administration for rapid reversal of heparin anticoagulation [1]. Respiratory (wheezing), cardiovascular (pulmonary vasoconstriction, pulmonary artery hypertension, hypotension, decreased cardiac contractility, bradycardia, cardiac arrest and ventricular fibrillation), skin (flushing, urticaria, and angioedema) and hematological (bleeding) have been reported [1]. Protamine reactionsare both immunologically mediated and a result of direct toxicity $[\mathbf{1 , 2}]$.

Contrary to cardiopulmonary bypass (CPB) which activates the alternative complement pathway, especially through surface contact in the oxygenator [3-5], protamine activates the complement system through the classical pathway. After cardiopulmonary bypass (CPB), administering protamine in a higher dose given over a shorter time ( $<5$ minutes) increases the risk for pulmonary and hemodynamic adverse reactions [6].

The optimal dose of protamine for hemostasis has achieved great interest: an excessive dose of protamine after CPB can prolong ACT and decrease platelet function [7], but it has not been confirmed that this leads to increased postoperative bleeding $[\mathbf{8}, \mathbf{9}]$. Khan et al., [8] demonstrated a hypocoagulative thrombelastography pattern when excess protamine was added in-vitro to blood samples from heparinized patients undergoing cardiac surgery with CPB, but did not investigate whether this had any significance for actual postoperative bleeding. Free protamine together with heparin in plasma seems to affect platelet function less than free protamine without heparin [10]. Thromboelastography has the best predictability/accuracy so far amongst routine tests for post-CPB bleeding [11,12]. The effects of different protamine dosages on complement activation and viscoelastic coagulation tests / postoperative bleeding, have not been studied.

The aim of this prospective, randomized and open study was to evaluate a reduced dose of protamine, infused over 20 minutes with a syringe driver on complement activation, Sonoclot coagulation analysis and clinical bleeding parameters in patients undergoing CABG. Our hypothesis was that a reduced protamine dose would decrease complement activation without increased postoperative drainage bleeding.

\section{Material and methods}

The study was prospective, open study, with no withdrawals or drop-outs. Following a pilot study on different levels of complement activation after cardiac surgery with two different dose regimes of protamine, whose patients are not included 
Schaub et al. Cardiovascular System 2013,

in this study, we anticipated a sample size of 40 patients to reach a power of $>0.80$ in a study with 2 different protamine dosages.

Forty patients with stable angina pectoris, scheduled for primary elective CABG surgery were prospectively randomized into two groups, 20 patients in each group. Patients were eligible for inclusion if they were planned for elective CABG for stabile angina and had given written consent. Patients with known coagulation or bleeding disorders were excluded, as were patients participating in other clinical studies. An informed and written consent was obtained preoperatively from each patient for the use of their personal data for scientific purposes according to the Helsinki Declaration. The study was approved by the local ethics committee (Örebro University Hospital) and conducted at that same hospital.

Patients received one of two schematic protamine chloride (porcine mucine heparin, Leo Pharma, Sweden) dosages of either $2 \mathrm{mg} / \mathrm{kg}$ or $4 \mathrm{mg} / \mathrm{kg}$ bodyweight (BW). The $4 \mathrm{mg} / \mathrm{kg} \mathrm{BW}$ protamine dose corresponds to the commonly recommended protamine dose for heparin reversal after CPB/CABG of $1 \mathrm{mg} / 100 \mathrm{IU}$ heparin. A study nurse broke the sequentially numbered opaque sealed randomization envelope for each patient at the time of the operation. Infusion was achieved using a syringe driver over 20 minutes after the end of CPB. The study nurse also collected blood samples at the scheduled time intervals. Additional protamine was permitted in dosages of $25 \mathrm{mg}$ first $1 \mathrm{~h}$ after the protamine infusion, and was indicated by increased drainage bleeding $(>100 \mathrm{ml} / \mathrm{h}$ during each of the following 3 hours and $>50 \mathrm{ml} / \mathrm{h}$ thereafter).

Hemochron ${ }^{\circledR}$ JR-ACT ((International Technidyne Corp, NJ, USA) was measured before and after additional protamine. Postoperative drainage blood loss was evaluated up to $25 \mathrm{~h}$ after the protamine infusion. Blood was autotransfused from the oxygenator reservoir up to $5 \mathrm{~h}$ after the protamine infusion.

The safety monitoring consisted of registration of heart rate, blood pressure, respiratory pressures, respiratory volume/ pressure loops/dynamic compliance and adverse events (with special consideration of postoperative bleeding.

An initial full dose of heparin (porcine-based standard heparin, Leo, Sweden), $300 \mathrm{lU} / \mathrm{kg}$ body weight was given to all patients. If insufficient heparinization with ACT $<480$ seconds was not achieved, extra heparin was administered before cardiac cannulation in repeated doses of $5000 \mathrm{IU}$ up to $500 \mathrm{IU} /$ $\mathrm{kg} \mathrm{BW}$. ACT was maintained $>480$ s during CPB according to recommendations from the manufacturer of the oxygenator. CPB was performed with a heart-lung machine (Stöckert SIII, Germany), the membrane oxygenator (D903 Avant, Dideco, Italy) being primed with $2 \mathrm{~L}$ of crystalloid. 10000 IE heparin was added to the pump prime of the heart-lung machine. $\mathrm{CPB}$ was conducted with moderate hypothermia of $30-32^{\circ} \mathrm{C}$ (rectal temperature) and a flow rate of $2.4 \mathrm{~L} / \mathrm{min} / \mathrm{m}^{2}$. Pulsative blood flow was not maintained during the CPB period.

The patients received standard anaesthesia with fentanyl, thiopentone, isoflourane and pancuronium, and were monitored using arterial and central venous catheters and respiration loops (AS3, Datex, Finland).

Blood was sampled from indwelling arterial catheters with vacutainer technique (Venoject, UK) into EDTA glass test tubes containing 0.38 M EDTA-K3 (Becton Dickinson, USA). Blood was sampled prior to induction, after sternotomy, after CPBstart, before protamine, 0.3 hours (h), $1 \mathrm{~h}, 3 \mathrm{~h}, 6 \mathrm{~h}$ and $24 \mathrm{~h}$ after protamine infusion. Activated complement, C3a-desArg and C4a-desArg were analysed from plasma frozen to - $70 \mathrm{C}$ using radioimmunoassay methods from Kabi UpJohn Diagnostics (Kabi Upjohn Company, Kalamazoo, USA) as has been described in a previous study [13].

Arterial blood gas analysis (Radiometer, Denmark) also included hemoglobin $(\mathrm{Hb})$. Routine laboratory analyses included platelet (plc) and leucocyte count (LC), activated partial thromboplastin time (aPTT), fibrinogen and antithrombin and were performed preoperatively, $2 \mathrm{~h}$ after and $25 \mathrm{~h}$ after protamine.

A Sonoclot coagulation analyser (Sienco Inc, Boulder, CO, USA) was used for viscoelastic native whole blood coagulation analyses as described in a recent study [14] with SonACT celite activated cuvettes - ACT, clot rate (CR) and time to peak (ttP) were registered.

Statistical analyses with T-tests were performed to determine whether there were differences between groups with respect to demographic and bleeding data. Individual changes from the starting values for arterial blood pressures, CVP, peak respiratory pressures, laboratory and Sonoclot coagulation data were analyzed by repeated ANOVAs with the factors time, treatment and patient within treatment. The first two factors were considered as fixed factors and the last (patient within treatment) as a random factor. Significant interactions were tested by Tukey's test. Residuals were examined and transformations were made if necessary. Bonferoni corrections were made for multiple comparisons. A statistical difference with a $p<0.05$ was regarded as significant (marked as $\mathrm{x}$ for intergroup comparisons in Figures and Table).

\section{Results}

All laboratory and bleeding data were normal distributed according to histogram displays and kurtosis and skewness testing with SPSS software, and are expressed as mean +-SEM (standard error of mean). There were no significant differences $(\mathrm{p}>0.05)$ in demographic data (sex, age, body mass index (BMI)), heparin dosages, extracorporeal circulation (ECC), time aortic clamping-time, additive protamine dosages, antithrombin, fibrinogen, aPTT, total blood loss and blood transfusion between the groups (Table 1, mean + standard error of mean (SEM)). Hourly drainage bleeding and autotransfusion up to $5 \mathrm{~h}$ post protamine are shown in Figure 1 (mean + SEM), with no significant statistical differences $(p>0.05)$. Mean+ SEM changes in $\mathrm{Hb}$, plc and $\mathrm{LC}$ are shown in Figure 2. There were only significant statistical differences between the groups in LC at 3-5h. 
Schaub et al. Cardiovascular System 2013,

http://www.hoajonline.com/journals/pdf/2052-4358-1-1.pdf

doi: $10.7243 / 2052-4358-1-1$

Table 1. Demographic, mean (sem) transfusion, anticoagulation, surgical and laboratory data from the two groups (mean +SEM). There were no significant differences between the groups.

\begin{tabular}{lll}
\hline Group & $\begin{array}{l}\mathbf{2} \mathbf{~ m g} / \mathbf{k g} \text { protmine } \\
(\mathbf{n}=\mathbf{2 0})\end{array}$ & $\begin{array}{l}\mathbf{4 m g} / \mathbf{k g} \text { protamine } \\
(\mathbf{n}=\mathbf{2 0})\end{array}$ \\
\hline Gender (male/female) & $15 / 5$ & $16 / 4$ \\
Age & $60(5)$ & $61(5)$ \\
BMI & $27.65(0.8)$ & $26(0.8)$ \\
Initial heparin dose (ml) & $4.8(0.2)$ & $4.8(0.2)$ \\
Extra heparin dose (ml) & $\mathrm{n}=62.3(0.3)$ & $\mathrm{n}=71.8(0.2)$ \\
Protamine dose/IU heparin & $0,54 \mathrm{mg} / 100 \mathrm{IU}$ & $0.96 \mathrm{mg} / 100 \mathrm{IU}$ \\
ECC time (min) & $110(5)$ & $96(8)$ \\
Aortic clamping time (min) & $58(4)$ & $55(5)$ \\
ERC transfusion during surgery (units) & $0.6(0.2)$ & $0.3(0.1)$ \\
ERC transfusion after surgery (units) & $0.9(0.2)$ & $0.5(0.2)$ \\
Total bleeding (ml) & $999(53)$ & $887(75)$ \\
Antithrombin preop-25h & $0.95(0.02)-0.7(0.07)$ & $1.0(0.03)-0.7(0.05)$ \\
aPTT ( s) preop-6h-25h & $27-34-28$ & $27-30-28$ \\
Fibrinogen (gram/L) preop-6h-25h & $3.6-2.3-3.2$ & $3.9-2.9-3.7$ \\
\hline
\end{tabular}
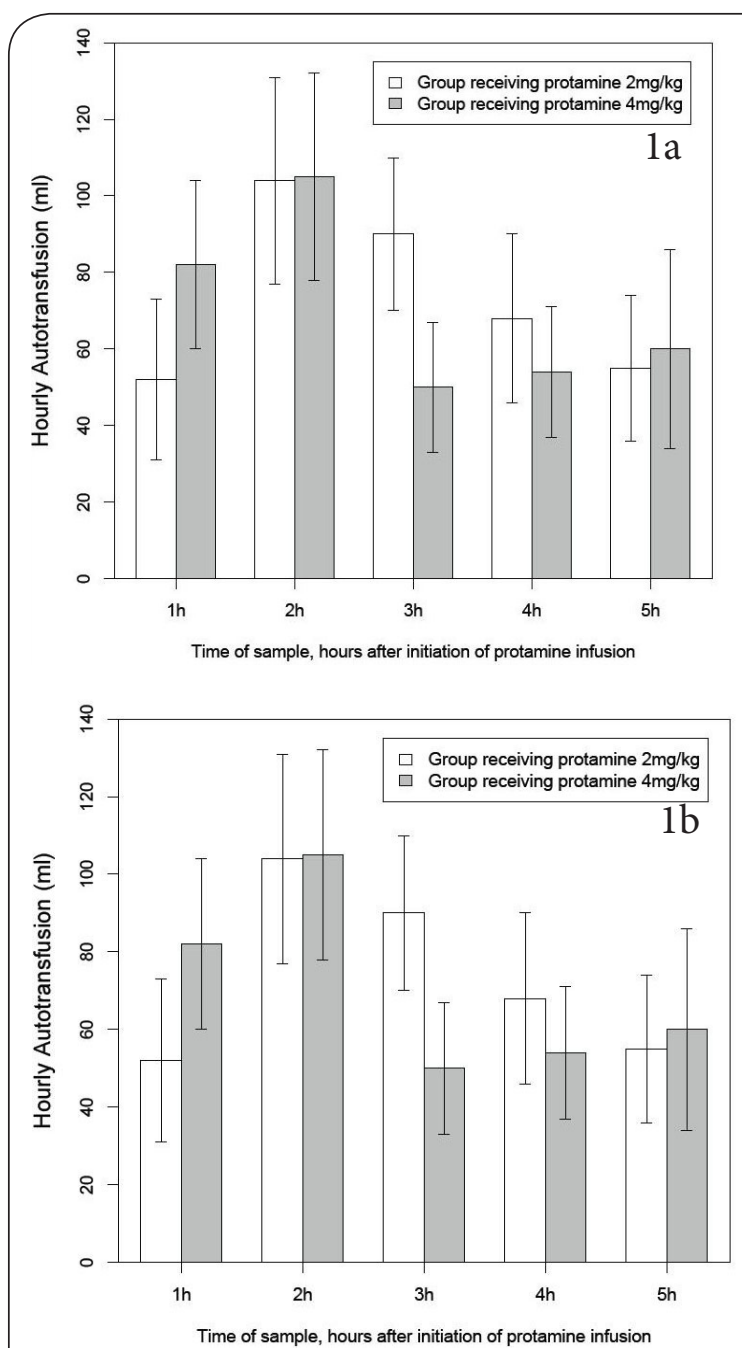

Figure $\mathbf{1} \mathbf{a}+\mathbf{b}$. Hourly drainage bleeding and autotransfusion. There were no significant intergroup differences up to 5 hours postoperatively (mean +SEM).
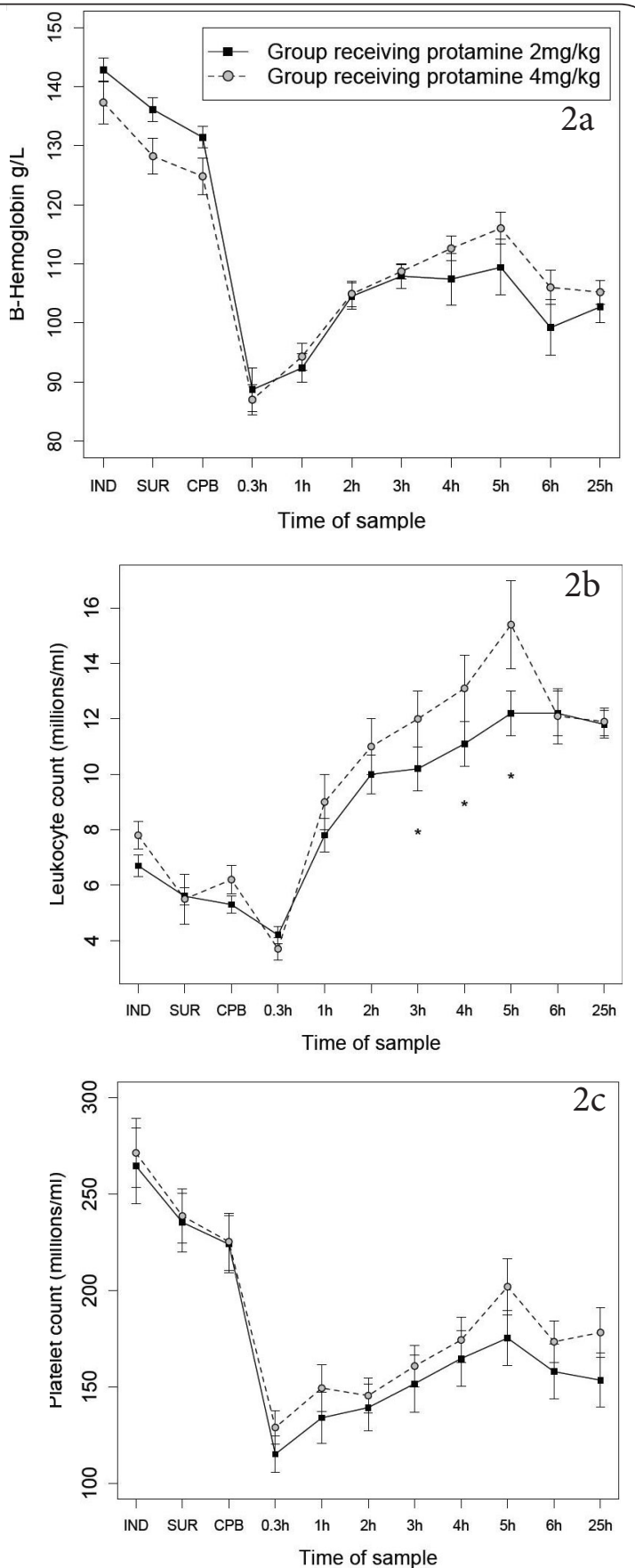

Figure $\mathbf{2} \mathbf{a}+\mathbf{b}+\mathbf{c}$. Changes in hemoglobin $(\mathrm{Hb})$, platelet (plc) and leucocyte count (LC)(mean +SEM). LC was significantly higher $\left.{ }^{*}\right)$ at 3-5 hours in the group receiving $4 \mathrm{mg} / \mathrm{kgprotamine}$. There were no significant intergroup differences in $\mathrm{Hb}$ or plc between the groups.

Significantly higher $(p<0.05)$ plasma levels of $C 3 a-d e s A r g$ were seen with the higher protamine dose $(4 \mathrm{mg} / \mathrm{kg} \mathrm{BW})$ up to $0.6 \mathrm{~h}$ post-protamine compared to the $2 \mathrm{mg} / \mathrm{kg}$ BW dose (Figure 3, mean+SEM). C3a-desArg increased significantly from before protamine up to $3 \mathrm{~h}$ post-protamine as compared 
Schaub et al. Cardiovascular System 2013,

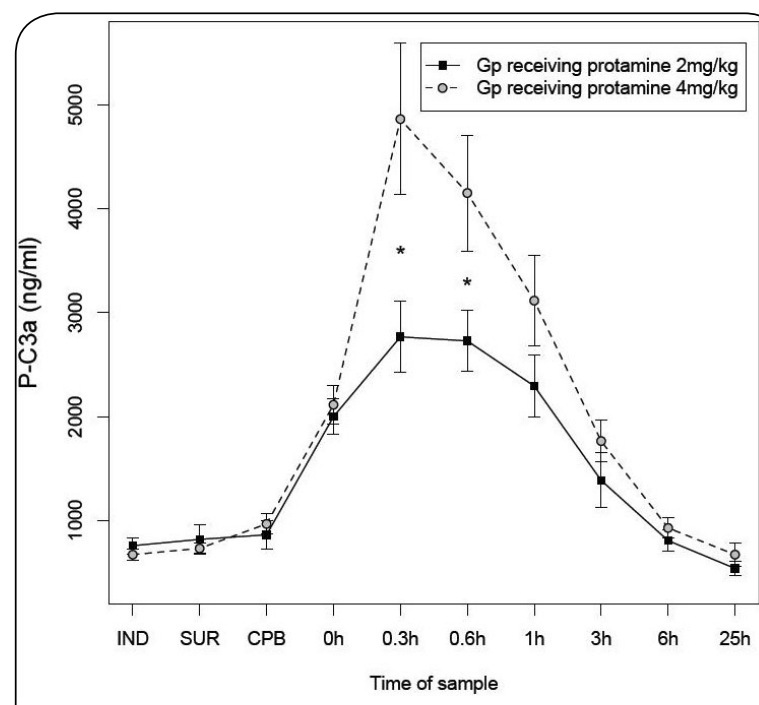

Figure 3. C3a-desarg changes in the two protamine dosage groups (mean + SEM).C3a was significantly higher $\left(^{*}\right)$ at 0,3 and $0,6 \mathrm{~h}$ in the group receiving $4 \mathrm{mg} / \mathrm{kg}$ protamine.

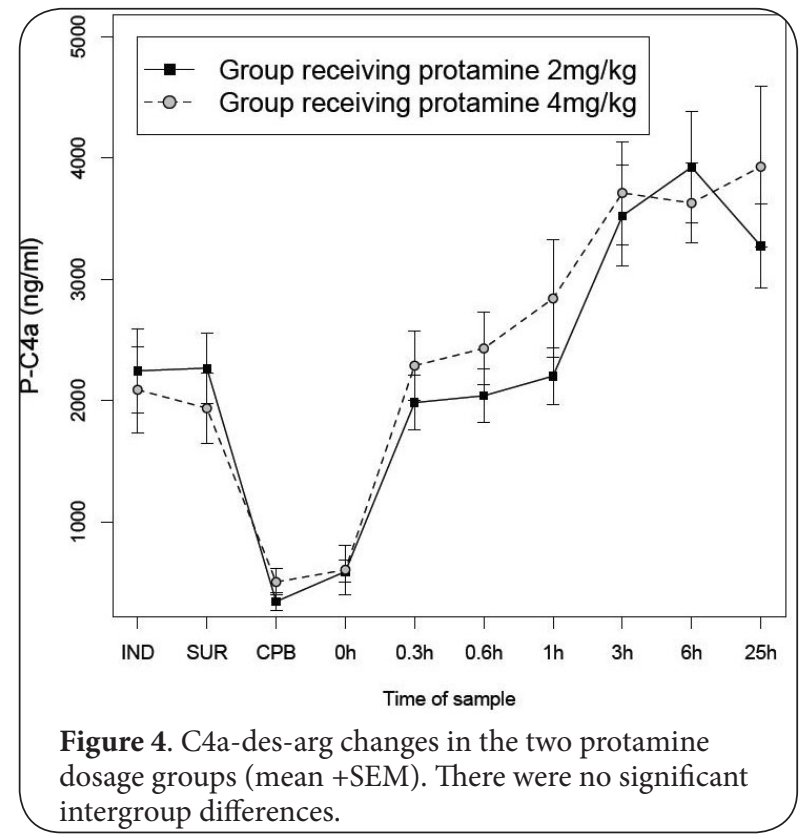

to preoperative values in both groups (Figure 3) C4a did not significantly differ between the groups, but increased significantly compared to preoperative baseline plasma levels in both groups from $3 \mathrm{~h}$ and onwards (Figure 4, mean+SEM).

Sonoclot parameters ACT, clot rate $(C R)$ and time to peak (ttP) significantly differed between the groups $(p<0.01-0.001)$ after protamine up to $4 \mathrm{~h}$ (ACT/CR) and $5 \mathrm{~h}$ (ttP) (Figure 5, mean+SEM). Intragroup comparison indicated a postoperative hypercoagulability in the $4 \mathrm{mg} / \mathrm{kg}$ BW protamine group for ACT, CR and ttP. Sonoclot-ACT correlated with Hemochron-ACT with

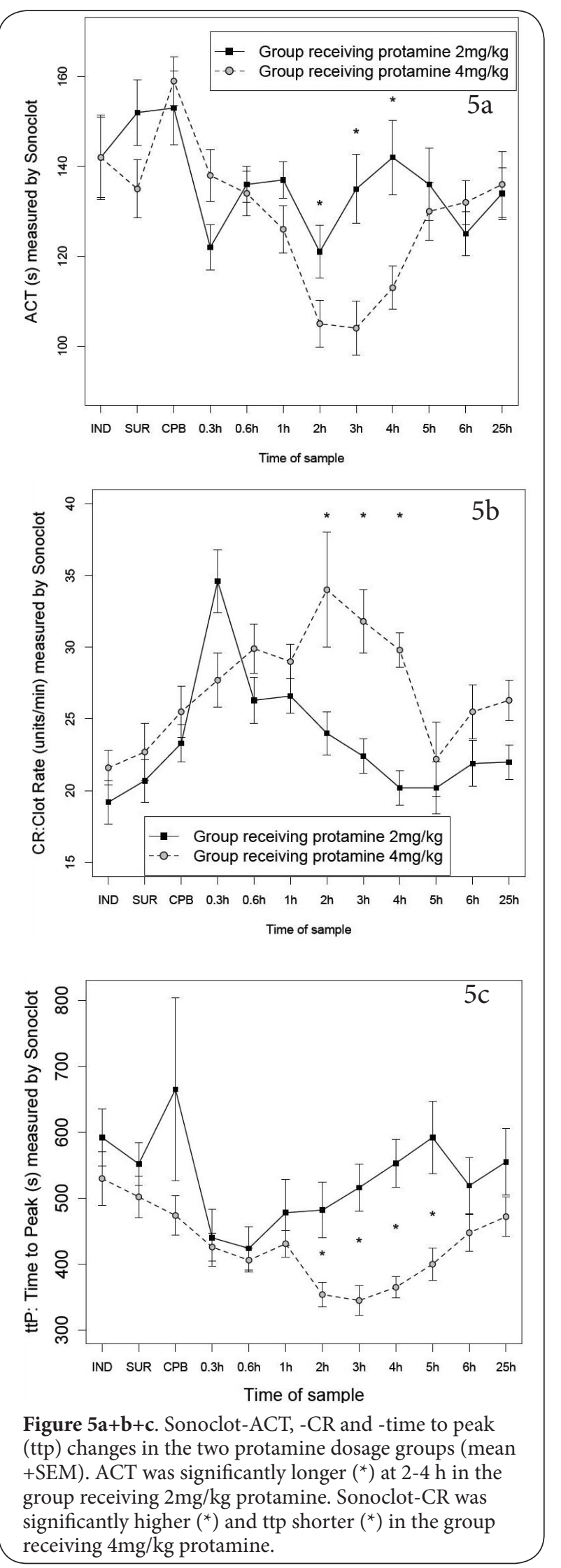


Schaub et al. Cardiovascular System 2013,

a significant $(p<0.001)$ regression factor 0.92 .

\section{Discussion}

With the introduction of radioimmunosassays (RIA) in the early 1970's, complement activation during cardiopulmonary bypass could be detected at low levels [7]. RIA-tests for C3a, C4a and C5a were made commercially available, and increased plasma levels of these so called anaphylatoxins could be detected in a multitude of clinical and experimental settings. Complement may be activated by either the classical ( $\mathrm{C} 4 \mathrm{a}$, C3a) or alternate pathway (C3a) during CPB. The systemic effects of the anaphylatoxins are normally well regulated by the activity of carboxypeptidase and by the rapid influx to sites of complement activation of neutrophils and monocytes, whose receptors act as a sink for $\mathrm{C5a}$, which is internalized and inactivated by proteolysis [15]. Although C5a is the strong estanaphylatoxin and chemoattractant, increased plasma levels have seldom been detected during CPB due to this internalization [16]. All of these peptides have anaphylatoxic activity, they cause smooth muscle contraction and degranulation of mast cells and basophils, with consequent release of histamine and other vasoactive substances that induce capillary leakage.

$\mathrm{C} 5 \mathrm{a}$ is the most potent of these anaphylatoxins. C5a and $\mathrm{C} 3 \mathrm{a}$ also have immunoregulatory effects on $\mathrm{T}$ cell function, either stimulating or inhibiting aspects of cell-mediated immunity [17]. Due to a $100 \%$ cross reactivity between C3a, $\mathrm{C} 4 \mathrm{a}$ and $\mathrm{C} 5 \mathrm{a}$ and their respective desarginated inactive degradation products $\mathrm{C} 3 \mathrm{a}$-desArg, $\mathrm{C} 4 \mathrm{a}$-desArg and $\mathrm{C} 5 \mathrm{a}-$ desArg (C5a-desArg retains 10\% anaphylactoid activity) the pathophysiological meaning of the increased plasma levels of the anaphylatoxins have not always been clear [18]. Species differences in the complement system and its interaction with neutrophils/monocytes/macrophages and their release reactions of intracellular enzymes, free radicals, leukotrienes and thromboxanes have been clarified [19].

With introduction of new and more specific monoclonal, neoantigenic antibody assays for complement activation/ complement spilt products (ELISA), terminal complement complex (TCC), complement receptors and introduction of antibody-designed antagonists of different activation products and receptors, a better understanding of the complement system and its pathophysiology has evolved $[\mathbf{2 0}, \mathbf{2 1}]$.

There were no differences in $\mathrm{C} 3 \mathrm{a}$ and $\mathrm{C} 4 \mathrm{a}$ between the groups intraoperatively prior to the protamine infusion. A significant increase in $\mathrm{C} 3 \mathrm{a}$ and for $\mathrm{C} 4 \mathrm{a}$ (Figures 3 and 4) could be seen as compared to preoperative values. C3a usually starts to increase shortly after the onset of CPB with a continuing rise during the bypass. Complement activation during cardiac surgery has also been associated with heparin, antibiotics, blood products and volume expanders during cardiopulmonary bypass [22]. Membrane oxygenators appear to diminish the degree of complement activation [22]. The introduction of heparin coated ECC systems has also decreased complement activation during CPB [3].

Significantly higher plasma levels of C3a-desArg were seen with the $4 \mathrm{mg} / \mathrm{kg}$ BW protamine dosage up to $0.6 \mathrm{~h}$ post-protamine compared to the $2 \mathrm{mg} / \mathrm{kg}$ BW dosage (Figure 3). Protamine can decrease carboxypeptidase (CPN) and thereby enhance complement activation effects ${ }^{2}$. This has been opposed by Rabito et al., [23] who only found the decrease in CPN during CPB to be caused by dilution and not to changes in CPN synthesis, catabolism or protamine. Cardiac, pulmonary, renal and hematological dysfunction after CBP, longer elapsed times of bypass and younger age at operation have been correlated to increased levels of C3a/ C3a-desArg [24].

No such correlations were found in this study. Furthermore, no deterioration in hemodynamics or pulmonary function could be correlated to the higher complement activation in patients with the $4 \mathrm{mg} / \mathrm{kg}$ protamine dose regime. Current CBP pathophysiology focuses on other immunologic markers than complement and more sophisticated tests of organ dysfunction probably need to be used instead of the routine hemodynamic monitoring, Servo 300C-derived respiratory parameters and blood gas analyses [25].

A rapid protamine injection/infusion can induce hypotension. This rate or free-concentration-dependent hypotension may result from several causes. Proposed explanations include stimulation of endothelium-derived relaxing factor release, inhibition of plasma carboxypeptidase $\mathrm{N}$, inactivation of various vasoactive peptides, and a non-immunologic release of histamine from mast cells. Histamine can be released by protamine from isolated human cutaneous mast cells at high concentrations but not from lung mast cells. Some protamine reactions may be associated with complement activation via the classical pathway, either through protamine-heparin complexes or through protamine and anti-IgG-antibody interaction. The generation of anaphylatoxins may induce mediator release from mast cells and can also stimulate the generation of new mediators, such as thromboxane A2 from membrane phospholipids of activated leucocytes $[\mathbf{1}, \mathbf{2}, \mathbf{5}, \mathbf{1 6}, \mathbf{1 8}]$.

Other reactions probably represent classical immunoglobulin E (IgE)-mediated allergy and present as classical anaphylactic reactions with rash, urticaria, bronchospasm, and systemic vasodilation. A pronounced increase in pulmonary artery pressure from pulmonary vasoconstriction with secondary right heart failure is seen in some patients. This reaction is probably mediated by release of thromboxane $A 2$ into the plasma, since its metabolite, thromboxane B2 concentration correlates to the degree of vasoconstriction [1].

Prior exposure to protamine from protamine containing insulin (now uncommon) increases the risk of severe protamine reaction during CPB [1]. Only one patient in our study had insulin treated diabetes and there were no signs of anaphylactic reaction in this patient nor exaggerate complement activation. None of our patients had received heparin before.

The presence of cross-reacting antibodies in patients with 
Schaub et al. Cardiovascular System 2013,

fish allergies or previous vasectomy has also been implicated as a risk factor for severe protamine reaction, but the evidence is limited to case reports and has not been verified in a series of such patients [1]. None of our patients had fish allergy or had undergone vasectomy. Diabetes, valvular surgery, and preexisting pulmonary hypertension have been suggested to be risk factors for pulmonary vasoconstriction but the data does not support these suggestions [2]. Only one of our patients was diabetic (Table 1), and no pulmonary reaction or difference in complement activation could be detected. Although the infusion rate may not affect lgG or IgE-mediated anaphylactic reactions, it attenuates responses that may depend on the concentration of free protamine and circulating heparin-protamine complexes [1]. A slow infusion rate is always advisable [6].

Protamine excess may increase ACT, decrease platelet aggregation and worsen thrombin function in vitro [9]. The plasma level of free protamine required for these phenomena to reach clinical significance remains uncertain: one somewhat aged study suggests that large excesses of protamine are clinical insignificant [26] but only tests of plasma coagulation and not platelet function or bleeding outcomes were used. ACT is a non-specific test for detection of heparin rebound [9].

An intra-group hypercoagulative Sonoclot response was seen with the higher protamine dose in the present study with higher clot rate and stronger platelet function, but also as compare to preoperative baseline values. Increased platelet activity and high fibrin deposition rates in viscoelastic tests have been associated with venoarterial thrombosis, TIA/ stroke, graft occlusion after aortofemoral-bypass surgery and in cancer $[27,28]$. Protamine infusion may both stimulate platelet-activating factor (PAF) biosynthesis by leukocytes in the lung and accelerate the disappearance of PAF in the arterial bed. An imbalance in such mechanisms may favour platelet aggregation, explaining stronger platelet activity as indicated by the shorter time to peak in the Sonoclot. Complement activation may play a role in this hypercoagulative response, due to its several bridges to the coagulation cascade [29]. Leucocyte count (LC) was higher after protamine in the $4 \mathrm{mg} /$ $\mathrm{kg}$ BW protamine group (Figure 5) and this may also induce a hypercoagulative response.

The significantly prolonged ACT in both the Sonoclot and Hemochron (not shown) with the lower dose of protamine probably indicate unblocked heparin with inhibition of fibrin and platelets as indicated by the decrease in CR and prolongation of time to peak (Figure 5). The most commonly used protamine protocols determine the reversal dose of protamine based on the total dose of heparin given during bypass, using a reversal ratio of 1 to $1.5 \mathrm{mg}$ protamine per 100 $U$ heparin. These methods do not account for the elimination of heparin during bypass and may result in substantial overdose of protamine. The protamine doses calculated from the heparin dose-ACT response curve, heparin level measurement (heparin-protamine titration - Hemotec ${ }^{\circledast}$ ), or protamine dose-ACT response in vitro (Hemochron) all result in lower doses [9] as the more advanced Hepcon HMS. Reduced-dose protamine protocols should be used since they have been associated with less bleeding [9].

Additional small doses of protamine may be warranted after reinfusion of blood remaining in the CPB circuit after decannulation. There was no difference in extra doses of protamine in our two groups (Table 1). The completeness of the heparin reversal is assessed 5 to 10 minutes after the end of infusion by measuring ACT. If the ACT has returned to baseline, heparin level measurement can also be helpful in ascertaining whether the dose of protamine has been sufficient [9]. ACT will be consistently prolonged only after heparin concentrations exceeding $0.1 \mathrm{U} / \mathrm{ml}$. A normal ACT does not preclude the presence of a significant amount of heparin [9] since the reagent formulations being used are designed for high dose heparin management and are less responsive to residual levels of heparin. Heparinase coupled to ACT methodology seems to be a promising and practical way to uncover residual unneutralized heparin [9]. We did not give extra protamine during the first hour as we wanted to clearly separate the degree of complement activation in the two groups. ACT was higher and Sonoclot indicated unblocked heparin in the group receiving the lower dose of protamine. The transfusion of ERC, hourly drainage bleeding and autotransfusion were all higher in the low protamine dosage group - and would probably become significant with more study patients. Especially the almost $50 \%$ higher transfusion rate in the low protamine dosage group and this difference still being nonsignificant indicates that our study is underpowered.

Although initial neutralization of heparin with all of the previously described methods is adequate, small amounts of free heparin can be detected with chromogenic substrate assay or repeat protamine titration between 1 and 5 hours after neutralisation [9]. Heparin level measurement at the end of bypass may be the most practical of these protocols. In the absence of a heparin level measuring devices, a dose of $1 \mathrm{mg}$ protamine for each $100 \mathrm{U}$ heparin given before CPB will almost invariably result in complete reversal of heparin [30].

There are several limitations of our study. First the power was calculated on protamine activation of $\mathrm{C} 3 \mathrm{a}$, and here we saw a significant dose response $(p<0.05)$, whereas none of the clinical parameters (hemodynamic, respiratory, bleeding and transfusion parameters) significantly differed. The study is surely underpowered for detecting anaphylactic reactions as they are infrequent, especially so - when the protamine is given slowly as in the present study. There is a trend for increased ERC transfusion, autotransfusion, drainage bleeding, lowered postoperative haemoglobin in the low protamine group and together with the longer ACTs this indicates unblocked heparin. With more patients we would probably have seen significant differences in these data. Alternatively if we had chosen to block prolonged ACTs (>140 s), drainage 
Schaub et al. Cardiovascular System 2013,

bleeding, transfusion need would probably decrease in the low protamine group irrespective of the size of the study groups. Also we chose to nonblind the procedure, and this is a default in study design, possibly being outweighed by the same study nurse securing the protocol and sampling throughout the study.

In conclusion, keeping protamine dosages low will reduce complement activation. Sonoclot indicated a risk of immediate postoperative hypercoagulabity with unnecessarily high protamine doses with clot structure parameters CR and ttP, whereas both standard and Sonoclot-ACTs indicated initial insufficient heparin reversal, with increased bleeding and transfusions. The impact on early graft occlusions should be further studied with viscoelastic tests balancing postoperative coagulation.

\section{Competing interests}

The authors declare that they have no competing interests.

\section{Authors' contributions}

Schött planned the study (at the time of the study affiliated to Örebro University Hospital) and performed it together with Åkervall-Fridh. Medical student Schaub processed the draft together with Thomas and Schött.

Thomas made the graphs and statistics.

\section{Acknowledgement and funding}

The study was funded by Örebro County Council and ALF -ISEX University in Lund.

Publication history

Received: 5-Feb-2013 Revised:12-Feb-2013

Re-Revised: 19-Feb-2013 Accepted: 21-Feb-2013

Published: 27-Feb-2013

\section{References}

1. Porsche R and Brenner ZR: Allergy to protamine sulfate. Heart Lung 1999, 28:418-28. | Article | PubMed

2. Weiss ME and Adkinson NF, Jr.: Allergy to protamine. Clin Rev Allergy 1991, 9:339-55. | Article | PubMed

3. Tagarakis GI and Tsilimingas NB: Heparin-coated extracorporeal circulation systems in heart surgery. Recent Pat Cardiovasc Drug Discov 2009, 4:177-9. | Article | PubMed

4. Wendel HP and Ziemer G: Coating-techniques to improve the hemocompatibility of artificial devices used for extracorporeal circulation. Eur J Cardiothorac Surg 1999, 16:342-50. I Article I PubMed

5. Svennevig JL, Geiran OR, Karlsen H, Pedersen T, Mollnes TE, Kongsgard $\mathrm{U}$ and Froysaker $\mathrm{T}$ : Complement activation during extracorporeal circulation. In vitro comparison of Duraflo II heparin-coated and uncoated oxygenator circuits. J Thorac Cardiovasc Surg 1993, 106:46672. I Article I PubMed

6. Dunning J, Versteegh M, Fabbri A, Pavie A, Kolh P, Lockowandt $U$ and Nashef SA: Guideline on antiplatelet and anticoagulation management in cardiac surgery. Eur J Cardiothorac Surg 2008, 34:73-92. | Article | PubMed

7. Knudsen F and Andersen LW: Immunological aspects of cardiopulmonary bypass. J Cardiothorac Anesth 1990, 4:245-58. | PubMed

8. Khan NU, Wayne CK, Barker J and Strang T: The effects of protamine overdose on coagulation parameters as measured by the thrombelastograph. Eur J Anaesthesiol 2010, 27:624-7. | Article | PubMed

9. Despotis GJ, Gravlee G, Filos K and Levy J: Anticoagulation monitoring during cardiac surgery: a review of current and emerging techniques. Anesthesiology 1999, 91:1122-51. | Article | PubMed

10. Carr ME Jr, Carr SL. At high heparin concentrations, protamine concentrations which reverse heparin anticoagulant effects are insufficient to reverse heparin anti-platelet effects. Thromb Res 1994, 75:617-30. I Article

11. Ganter MT and Hofer CK: Coagulation monitoring: current techniques and clinical use of viscoelastic point-of-care coagulation devices. Anesth Analg 2008, 106:1366-75. | Article | PubMed

12. Forestier F, Belisle S, Contant C, Harel F, Janvier G and Hardy JF: [Reproducibility and interchangeability of the Thromboelastograph, Sonoclot and Hemochron activated coagulation time in cardiac surgery]. Can J Anaesth 2001, 48:902-10. | Article | PubMed

13. Norda R, Schott U, Berseus O, Akerblom O, Nilsson B, Ekdahl KN, Stegmayr BG and Knutson F: Complement activation products in liquid stored plasma and C3a kinetics after transfusion of autologous plasma. Vox Sang 2012, 102:125-33. | Article | PubMed

14. Schott U, Nilsson LG, Broman M and Engstrom M: Monitoring of low molecular weight heparin anticoagulation during haemodialysis with a Sonoclot Analyzer. Perfusion 2010, 25:191-6. I Article I PubMed

15. Manthey HD, Woodruff TM, Taylor SM and Monk PN: Complement component 5a (C5a). Int J Biochem Cell Biol 2009, 41:2114-7. | Article | PubMed

16. Bruins $P$, te Velthuis $H$, Eerenberg-Belmer AJ, Yazdanbakhsh AP, de Beaumont EM, Eijsman L, Trouwborst A and Hack CE: Heparin-protamine complexes and C-reactive protein induce activation of the classical complement pathway: studies in patients undergoing cardiac surgery and in vitro. Thromb Haemost 2000, 84:237-43. | Article | PubMed

17. Sacks SH: Complement fragments $\mathrm{C} 3 \mathrm{a}$ and $\mathrm{C5a}$ : the salt and pepper of the immune response. Eur J Immunol 2010, 40:668-70. | Article | PubMed

18. Levy JH and Tanaka KA: Inflammatory response to cardiopulmonary bypass. Ann Thorac Surg 2003, 75:S715-20. | Article | PubMed

19. Gillinov AM, Redmond JM, Winkelstein JA, Zehr KJ, Herskowitz A, Baumgartner WA and Cameron DE: Complement and neutrophil activation during cardiopulmonary bypass: a study in the complementdeficient dog. Ann Thorac Surg 1994, 57:345-52. | Article | PubMed

20. Mollnes TE, Jokiranta TS, Truedsson L, Nilsson B, Rodriguez de Cordoba $\mathrm{S}$ and Kirschfink $\mathrm{M}$ : Complement analysis in the 21st century. $\mathrm{Mol}$ Immunol 2007, 44:3838-49. | Article | PubMed

21. Oppermann $M$ and Wurzner R: Modern determination of complement activation. Semin Thromb Hemost 2010, 36:611-9. | Article I PubMed

22. Utley JR: Pathophysiology of cardiopulmonary bypass: current issues. J Card Surg 1990, 5:177-89. I PubMed

23. Rabito SF, Anders R, Soden W and Skidgel RA: Carboxypeptidase N concentration during cardiopulmonary bypass in humans. Can $\mathrm{J}$ Anaesth 1992, 39:54-9. | Article | PubMed

24. Kongsgaard UE, Smith-Erichsen N, Geiran O and Bjornskau L: Duration of cardiopulmonary bypass compared with changes in the plasma protease systems. Scand J Thorac Cardiovasc Surg 1991, 25:223-6. Article I PubMed

25. Gourlay T and Shedden L: The impact of different biocompatible coated cardiopulmonary bypass circuits on inflammatory response and oxidative stress. Perfusion 2010, 25:427-9; author reply 429-30. | Article I PubMed

26. Ellison $\mathrm{N}$, Ominsky $\mathrm{AJ}$ and Wollman $\mathrm{H}$ : Is protamine a clinically important anticoagulant? A negative answer. Anesthesiology 1971, 35:621-9. | Article | PubMed

27. Rafiq S, Johansson PI, Ostrowski SR, Stissing T and Steinbruchel DA: Hypercoagulability in patients undergoing coronary artery bypass grafting: prevalence, patient characteristics and postoperative outcome. Eur J Cardiothorac Surg 2012, 41:550-5. | Article | PubMed

28. Akay OM, Ustuner Z, Canturk Z, Mutlu FS and Gulbas Z: Laboratory investigation of hypercoagulability in cancer patients using rotation thrombelastography. Med Oncol 2009, 26:358-64. I Article I PubMed

29. Osterud B, Olsen JO and Benjaminsen AW: The role of complement in 
Schaub et al. Cardiovascular System 2013,

http://www.hoajonline.com/journals/pdf/2052-4358-1-1.pdf

the induction of thromboplastin synthesis. Haemostasis 1984, 14:386-

92. | Article | PubMed

30. Hirsh J and Raschke R: Heparin and low-molecular-weight heparin: the Seventh ACCP Conference on Antithrombotic and Thrombolytic Therapy. Chest 2004, 126:188S-203S. | Article | PubMed

\section{Citation:}

Schaub C, Thomas O D, Åkervall Fridh L and Schött U:

Protamine dosage effects on complement activation and sonoclot coagulation analysis after cardiac surgery. Cardiovascular System 2013, 1:1.

http://dx.doi.org/10.7243/2052-4358-1-1 